\section{Biostimulants on Nutritional Status and Fruit Production of Mango 'Kent' in the Brazilian Semiarid Region}

\author{
Jackson Teixeira Lobo ${ }^{1}$, Ítalo Herbert Lucena Cavalcante, \\ Augusto Miguel Nascimento Lima, Yuri Alysson Carvalho Vieira, \\ Pedro Igor Rodrigues Modesto, and Jenilton Gomes da Cunha \\ Department of Agricultural Science, Federal University of São Francisco \\ Valley, Rod. BR 407, km 190, Lote 543 PSNC, Petrolina, Pernambuco State, \\ 56.300-990, Brazil
}

Additional index words. fruit drop, floral management, Mangifera indica, plant nutrition, tropical plant

\begin{abstract}
Adequate nutritional status is fundamental for the fruiting process of mango trees (Mangifera indica L.). In this context, plant biostimulants are substances that promote physiological and nutritional changes, benefiting production. The present study evaluated the effect of biostimulants on the nutritional status and fruit production of 'Kent' mango trees. The experiment was carried out in the Brazilian semiarid region over 2 consecutive years, 2016 and 2017. Leaf treatments with biostimulants were applied in three phases (preflowering, beginning of flowering, and full flowering) during both seasons. The treatments were as follows: T1) control (without biostimulants); T2) biostimulants containing nutrients and $L-\alpha$-amino acids; T3) biostimulants containing nutrients and Lithothamnium algae extract; T4) biostimulants containing nutrients and sucrose; and T5) biostimulants containing nutrients, free amino acids, and Lithothamnium algae extract. The results show that there was no effect of the biostimulants for chlorophyll $a, b$, and total indices or for total leaf soluble carbohydrates. Some of the treatments affected the leaf concentrations of $\mathrm{N}, \mathrm{K}, \mathrm{Mn}, \mathrm{Fe}$, and $\mathrm{Zn}$, whereas only $\mathrm{T} 2$ in 2016 and $T 5$ in 2017 increased the number of fruits per panicle if compared with nontreated plants. In 2016, the production per tree was higher in T5 compared with the other treatments, whereas it was greater in 2017 in both $\mathrm{T} 2$ and $\mathrm{T} 5$ with increases of 37.4 and $23.1 \mathrm{~kg}$ per tree, respectively, compared with the control treatment. Biostimulants containing soluble nutrients, $L-\alpha$-amino acids, free amino acids, and Lithothamnium algae extract benefit the nutritional status and increase the fruit production of mango 'Kent'.
\end{abstract}

Brazil is the seventh largest producer of mango in the world (Food and Agriculture Organization of the United Nations, 2017), and in 2016, the country occupied the sixth position in exportation of the fruit, with a total of 154,211 tons, with $85 \%$ coming from the submiddle São Francisco Valley (Instituto Brasileiro de Geografia e Estatística, 2018). High fruit yield and quality are special features of the mango trees grown in this region.

The 'Kent' mango is one of the main commercial cultivars because of its physicochemical and sensorial characteristics, which are appealing to the international market. However, the cultivar presents intense fruit abscission during its productive cycle, which causes production and economic losses. Only a small portion of the fruits initially formed reaches maturity. This undesirable abscission

Received for publication 19 Nov. 2018. Accepted for publication 4 Mar. 2019.

The authors gratefully thank FACEPE (Foundation for Support of Science and Technology of Pernambuco State) for supporting this work under grant number IBPG-1002-5.01/15.

${ }^{1}$ Corresponding author. E-mail: jacksonteixeira78@ gmail.com. chitin and chitosan derivatives, antiperspirants, and free amino acids, plus substances containing nitrogen.

Singh and Janes (2000) studied the effects of exogenous application of polyamines on 'Kent' mango trees cultivated in western Australia and verified increased retention of fruits with the use of spermine. In Petrolina, Brazil, Gomes et al. (2008) recorded a $10.2 \%$ increase of production in 'Tommy Atkins' mango trees with the use of bioflavonoid- and phytoalexinbased biostimulants, which were applied during floral induction. Ahmed et al. (2015) verified that, in addition to production increase, the quality 'Taimour' mango fruits improved with the spraying of Ascophyllum nodosum seaweed extract. Khattab et al. (2016) found beneficial effects on fruit retention and fruit yield of 'Ewais' and 'Fagry Kelan' mango cultivars cultivated in Giza, Egypt, when using calcium, boron, and amino acid-based biostimulants. Although the beneficial effects of biostimulants have been proven, results evaluating its effects on 'Kent' mango grown in semiarid are still scarce in the scientific literature.

Therefore, the aim of this study was to evaluate the effects of biostimulant foliar applications on the nutritional status and fruit production of 'Kent' mango cultivated in semiarid conditions

\section{Materials and Methods}

Plant Material and Growing Conditions. Ten-year-old mango trees cv. Kent (Mangifera indica $\mathrm{L}$.) in their sixth productive year with uniform vigor and a 3.2-m canopy diameter were used in this study. The experiment was performed in two consecutive seasons (2016 and 2017) in an orchard located in Petrolina $\left(9^{\circ} 09^{\prime} \mathrm{S}, 40^{\circ} 22^{\prime} \mathrm{W}\right.$; altitude $365.5 \mathrm{~m}$ above sea level), state of Pernambuco, Brazil. The climate of this region is classified as Bswh (Köeppen), which corresponds to a semiarid region. During the experiment, the climatic data were collected by a meteorological station (Fig. 1).

The plants, spaced $5.0 \mathrm{~m}$ between the rows and $3.0 \mathrm{~m}$ between the plants, were irrigated daily (Micro sprinkler) with one emitter per tree, for a flow of nearly $60 \mathrm{~L} \cdot \mathrm{h}^{-1}$ each, based on evapotranspiration registers recorded by a meteorological and corrected according to the mango culture coefficient (Kc) defined by Genú and Pinto (2002).

Nutritional management of the orchard was carried out with a fertirrigation system according to the soil analysis (Table 1), leaf analysis (Table 2), and crop demand (Genú and Pinto, 2002). In each evaluation season (2016 and 2017), the following nutrients were applied: $97 \mathrm{~kg} \cdot \mathrm{ha}^{-1}$ of N, $111 \mathrm{~kg} \cdot \mathrm{ha}^{-1}$ of $\mathrm{P}_{2} \mathrm{O}_{5}, 163 \mathrm{~kg} \cdot \mathrm{ha}^{-1}$ of $\mathrm{K}_{2} \mathrm{O}, 115 \mathrm{~kg} \cdot \mathrm{ha}^{-1}$ of $\mathrm{Ca}, 2.3 \mathrm{~kg} \cdot \mathrm{ha}^{-1}$ of $\mathrm{B}$, and $11 \mathrm{~kg} \cdot \mathrm{ha}^{-1}$ of $\mathrm{Zn}$. Fertilizer nutrient sources were ammonium sulfate $(20 \% \mathrm{~N}$ and $22 \% \mathrm{~S})$, potassium sulfate $(50 \% \mathrm{~K}$ and $18 \% \mathrm{~S})$, zinc sulfate $(35 \% \mathrm{Zn}$ and $9 \% \mathrm{~S})$, boric acid (17\% B), monoammonium phosphate $(10 \% \mathrm{~N}$ and $21.8 \% \mathrm{P}), \mathrm{Ca}$ $\mathrm{Mg}$ fertilizer $(32 \% \mathrm{Ca}$ and $2 \% \mathrm{Mg})$, and compost leaf fertilizer $(1.5 \% \mathrm{~N}, 1 \% \mathrm{P}, 1.4 \%$ 
A

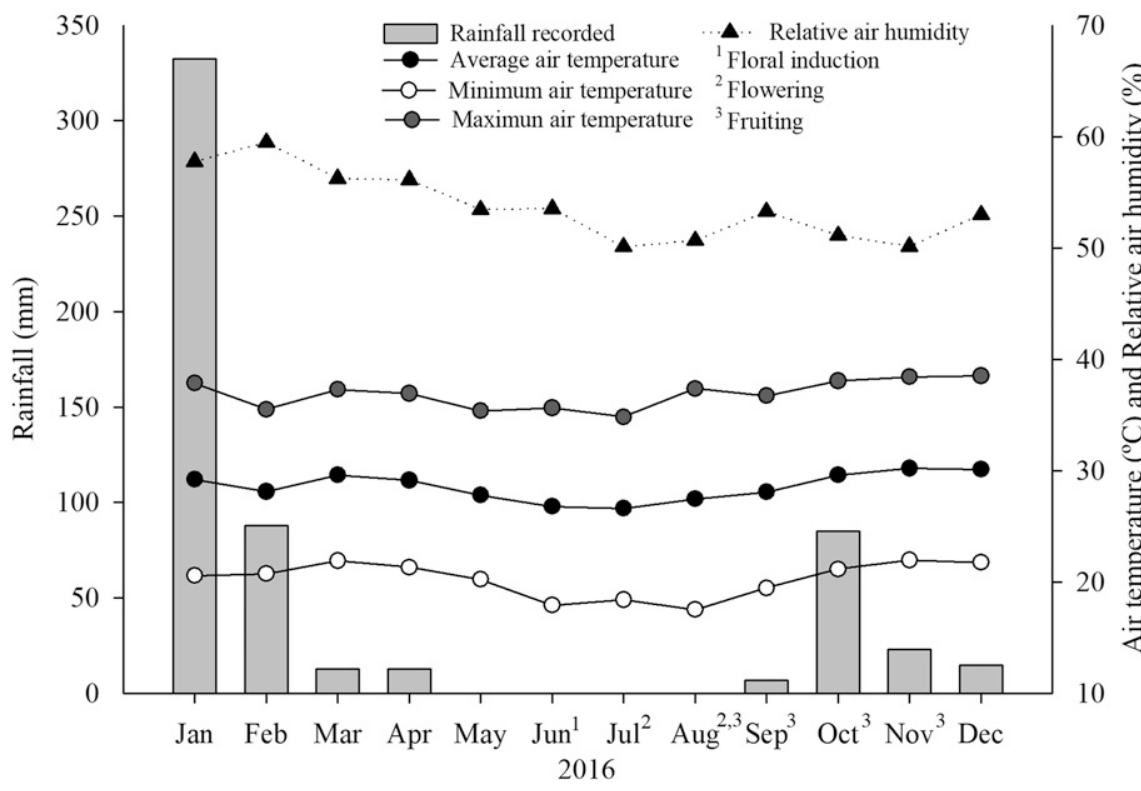

B

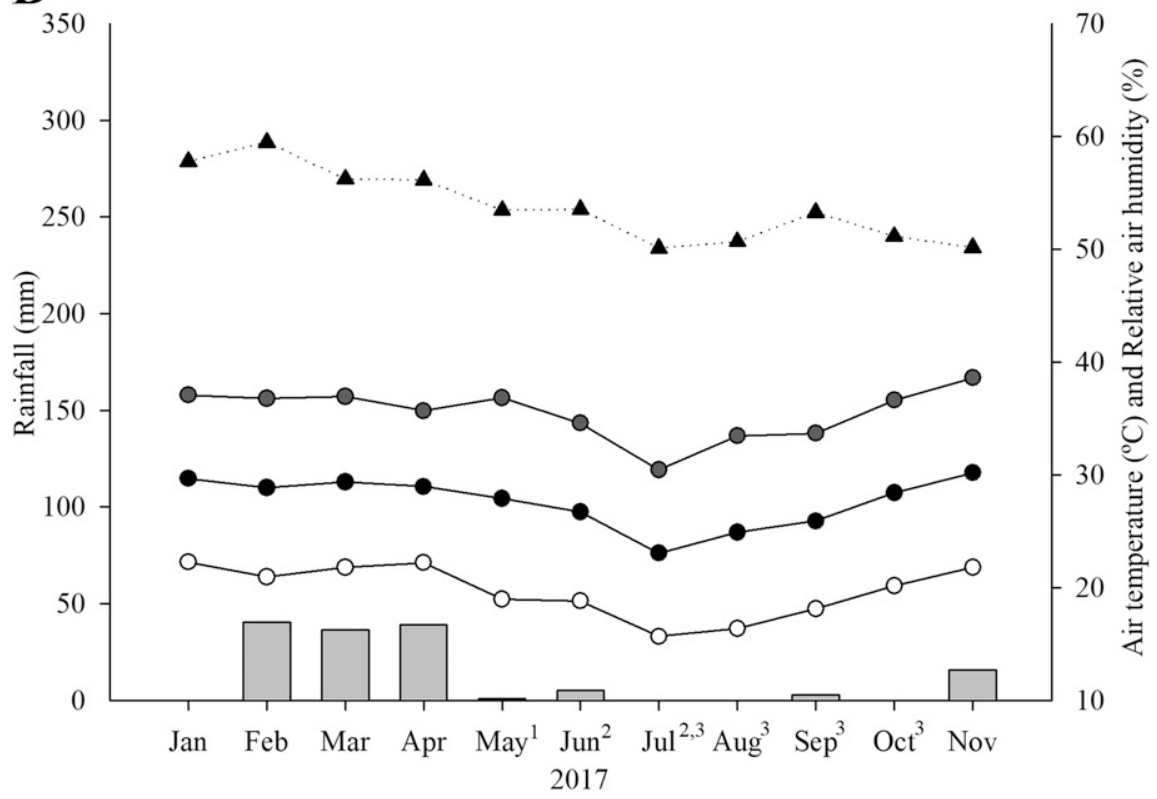

Fig. 1. Maximum, minimum, and average air temperature, relative air humidity, and rainfall recorded during the study. Petrolina, Pernambuco state, Brazil: 2016 (A) and 2017 (B).
$\mathrm{K}, 2.4 \% \mathrm{Ca}, 0.3 \% \mathrm{Mg}, 0.3 \% \mathrm{~S}, 18 \%$ total organic carbon, $26 \%$ fulvic acid, and $2.3 \%$ humic acid). In 2017, two fertigations were added with $50 \mathrm{~g}$ per tree of $\mathrm{H}_{3} \mathrm{BO}_{3}$ plus five sprays with $\mathrm{H}_{3} \mathrm{BO}_{3}$, the first two at $0.3 \%$ and the remaining at $0.2 \%$. During both seasons, plants were sprayed monthly $\left(2 \mathrm{~L} \cdot \mathrm{ha}^{-1}\right)$ with a leaf fertilizer composed of $11 \% \mathrm{~N}, 1 \% \mathrm{~K}_{2} \mathrm{O}$, and $6 \%$ total organic carbon.

Flowering management included paclobutrazol (PBZ) application and bud dormancy breaking according to the recommendations of Genú and Pinto (2002). The application of PBZ took place on 11 Mar. in in 2016 and 30 Jan. in 2017, which was $60 \mathrm{~d}$ after postharvest pruning. The dose used in each harvest time was $9 \mathrm{~mL}$ per meter of canopy diameter of Cultar 250 SC (Syngenta Crop Protection, Paulínia, São Paulo, Brazil), the equivalent of $2.25 \mathrm{~g} \cdot \mathrm{m}^{-1}$ a.i. diluted in $2 \mathrm{~L}$ of water and applied to the soil in the crown projection. Dormancy break included three foliar sprays with calcium nitrate $(2.5 \%)$ at 90,97 , and $104 \mathrm{~d}$ after PBZ application. All management practices (e.g., pruning; control of weeds, pests, and diseases) were performed following the instructions of Genú and Pinto (2002).

Treatments and experimental design. This experiment was analyzed as a randomized complete block design with five treatments, four replications per treatment, and four plants per replication, evaluated in two consecutive years, 2016 and 2017. Thus, the treatments consisted of foliar sprays with plant biostimulants, the compositions of which are described in Table 3.

The treatments were applied in three phases: preflowering, beginning of flowering, and full flowering, defined according to the criterion of Ramírez and Davenport (2010). The application dates for the 2016 season were 8 July (preflowering), 22 July (beginning of flowering), and 8 Aug. (full flowering) and for the 2017 season were 10 June (preflowering), 22 June (beginning of flowering), and 12 July (full flowering). These doses of applied foliar sprays of biostimulants where used as the recommendations of manufacturers, and the spraying volume was standardized in $3 \mathrm{~L}$ per tree in each application for all the treatments, in sufficient

Table 1. Chemical soil characteristics ( $0-40$ soil depth) in the experimental site before the experiment.

\begin{tabular}{|c|c|c|c|c|c|c|c|c|c|c|c|}
\hline & & & & $\mathrm{K}^{+}$ & $\mathrm{Na}^{+}$ & $\mathrm{Ca}^{2+}$ & $\mathrm{Mg}^{2+}$ & $\mathrm{Al}^{3+}$ & $(\mathrm{H}+\mathrm{Al})$ & $\mathrm{BS}$ & \\
\hline Depth $(\mathrm{cm})$ & ${ }^{\mathrm{z}} \mathrm{pH}\left(\mathrm{H}_{2} \mathrm{O}\right)$ & $\mathrm{OM}\left(\mathrm{g} \cdot 100 \mathrm{~g}^{-1}\right)$ & $\mathrm{P}\left(\mathrm{mg} \cdot \mathrm{dm}^{-3+}\right)$ & \multicolumn{7}{|c|}{$\mathrm{cmol}_{\mathrm{c}} \cdot \mathrm{dm}^{-3}$} & V (\%) \\
\hline$\overline{0-40}$ & 6.30 & 12.00 & 16.00 & 0.35 & 0.13 & 4.50 & 1.80 & 0.00 & 1.92 & 6.78 & 78.00 \\
\hline
\end{tabular}

${ }_{\mathrm{pH}}$ measured in water.

Extractors: $\mathrm{P}, \mathrm{K}$, and $\mathrm{Na}$ : Mehlich $\left(\mathrm{HCl}+\mathrm{H}_{2} \mathrm{SO}_{4}\right)$; $\mathrm{Ca}, \mathrm{Mg}$, and $\mathrm{Al}: \mathrm{KCl} 1 \mathrm{M}$. $\mathrm{BS}=$ base sum; $\mathrm{OM}=$ organic matter; $\mathrm{V}=$ percent base saturation.

Table 2. Leaf nutrients concentrations of mango cv. Kent before the treatments.

\begin{tabular}{|c|c|c|c|c|c|c|c|c|c|}
\hline & $\mathrm{N}$ & $\mathrm{P}$ & $\mathrm{K}$ & $\mathrm{Ca}$ & $\mathrm{Mg}$ & $\mathrm{Mn}$ & $\mathrm{Fe}$ & $\mathrm{Zn}$ & B \\
\hline Season & & & $\mathrm{g} \cdot \mathrm{kg}^{-1}$ & & & \multicolumn{4}{|c|}{$\mathrm{mg} \cdot \mathrm{kg}^{-1}$} \\
\hline 2017 & 13.49 & 1.54 & 8.90 & 15.60 & 1.50 & 171.78 & 41.28 & 15.08 & 97.65 \\
\hline
\end{tabular}

$\mathrm{N}$ by Kjeldahl method; P by spectrometry with vanadate yellow; K by flame photometry; $\mathrm{Mg}, \mathrm{Ca}, \mathrm{Fe}, \mathrm{Zn}$, and Mn by atomic absorption spectrophotometry; $\mathrm{B}$ by spectrophotometry with azomethine-H. 
quantity to completely wet the plants canopy, so that a 20 -L capacity backpack sprayer was used. A neutral detergent $\left(0.5 \mathrm{~mL} \cdot \mathrm{L}^{-1}\right)$ was added to the volume sprayed.

Variables analyzed. At full bloom, after the last application of all treatments, chlorophyll $a, b$, and total were determined using the electronic chlorophyll meter ClorofiLOG CFL 1030 (Falker, Porto Alegre, Rio Grande do Sul, Brazil), so that in each plant, three completely expanded and healthy leaves were randomly selected, and readings were made at three places, the base, middle region, and leaf apex, as recommended by ElHendawy et al. (2005).

At full bloom after the last application of all treatments were added, a sample composed of 12 leaves of the last vegetative flows randomly distributed in the four quadrants was collected for each plot to determine macro- and micronutrients levels. After washing with distilled water, the leaves were dried in an oven with forced air circulation at $60^{\circ} \mathrm{C}$, grinded using Willey knives with a 1$\mathrm{mm}$ mesh sieve, and stored in a hermetically sealed container for analysis.

The nitrogen contents were determined by the Kjeldahl method. To determine the other nutrients, the samples were incinerated in a muffle oven at $500{ }^{\circ} \mathrm{C}$ for $3 \mathrm{~h}$ and the ashes dissolved in nitric acid $\left(1 \mathrm{~mol} \cdot \mathrm{L}^{-1}\right)$ to obtain the extract. The phosphorus content was determined by the molybdovanadate method, the potassium content by emission flame spectrometry, the boron content by azomethine- $\mathrm{H}$ spectrometry, and calcium, magnesium, manganese, iron, and zinc contents by atomic absorption spectrometry according to the methodology proposed by Tedesco et al. (1995).

The determination of total soluble carbohydrates in the fresh weight leaves (FM) was carried out in the preflowering and flowering phases. The samples were collected using the same recommendations as those used for the nutrient analysis. The leaves were conditioned in plastic bags and kept under refrigeration for later determination by the phenol-sulfuric method proposed by Dubois et al. (1956).

At the beginning of flowering, 10 panicles randomly distributed in the four quadrants of each experimented tree's crown were marked to determine the length of each panicle during full flowering, using a graduated ruler (millimeters). During the harvest, the number of fruits per each panicle was counted in the same inflorescences where the length was evaluated.

Manual fruit harvesting took place on 20 Nov. 2016 and 31 Oct. 2017. At the time of "harvesting," the fruits were in stage 2 of development, characterized by the cream- yellow pulp color, as described by Filgueiras et al. (2000). The fruits of each tree were counted and weighed to obtain tree production (kilogram per tree).

Statistical analysis. Data from each season were individually submitted to analysis of variance to evaluate the significant effects by $F$ test. Treatment means were compared using the Tukey test $(P \leq 0.05)$, and correlation analysis between the variables was performed using the statistical software ASSISTAT 7.7 (Silva and Azevedo, 2016).

\section{Results}

Results of the analysis of variance (Table 4) indicate that there was no significant effect $(P>0.05)$ of the biostimulants on chlorophyll $a, b$, and total indices in either season. The average indices for the variables in 2016 were $36.44,15.78$, and $52.23 \mathrm{FCI}$ (Falker Chlorophyll Index), respectively, and 37.83, 13.67, and 51.50 FCI in 2017.

At the full-flowering phase, there was a significant effect $(P \leq 0.05)$ of the biostimulants on nitrogen, potassium, manganese, and iron contents in the 2016 season and on potassium, iron, and zinc in the 2017 season (Table 5).

In 2016, from the preflowering to the fullflowering stage, there were reductions in $\mathrm{N}$

Table 3. Treatment description and composition of the biostimulants used in the experiment.

\begin{tabular}{|c|c|c|}
\hline Treatment & Composition & Dose \\
\hline$\overline{\mathrm{T} 1}$ & Without biostimulants spray & - \\
\hline $\mathrm{T} 3$ & $\begin{array}{l}\text { Organic nitrogen } 5.0 \% \text {, nitric nitrogen } 1.2 \% \text {, ammoniacal nitrogen } 1.3 \% \text { and } \\
\text { amide nitrogen } 2.5 \% \text {; raw materials: water, soybean pie, liquid sodium hydroxide, urea, } \\
\text { ammonium nitrate, citric acid, Lithothannium seaweed extracts, and sodium molybdate }\end{array}$ & $1.0 \mathrm{~mL} \cdot \mathrm{L}^{-1}$ \\
\hline $\mathrm{T} 4$ & Calcium $8.0 \%$, boron $2.0 \%$, and sucrose & $2.5 \mathrm{~mL} \cdot \mathrm{L}^{-1}$ \\
\hline T5 & $\begin{array}{l}\text { Organic nitrogen } 6.0 \% \text {, organic carbon of biological origin } 20.8 \% \text { and total } \\
\text { protein } 31.0 \% \text {; raw materials: water, soybean pie, liquid sodium hydroxide, } \\
\text { leonardite, Lithothannium seaweed extracts, citric acid, and free amino acids }\end{array}$ & $2.5 \mathrm{~mL} \cdot \mathrm{L}^{-1}$ \\
\hline
\end{tabular}

Table 4. Chlorophyll $a$, chlorophyll $b$, total chlorophyll and total soluble carbohydrates in mango tree leaves cv. Kent as a function of biostimulant application.

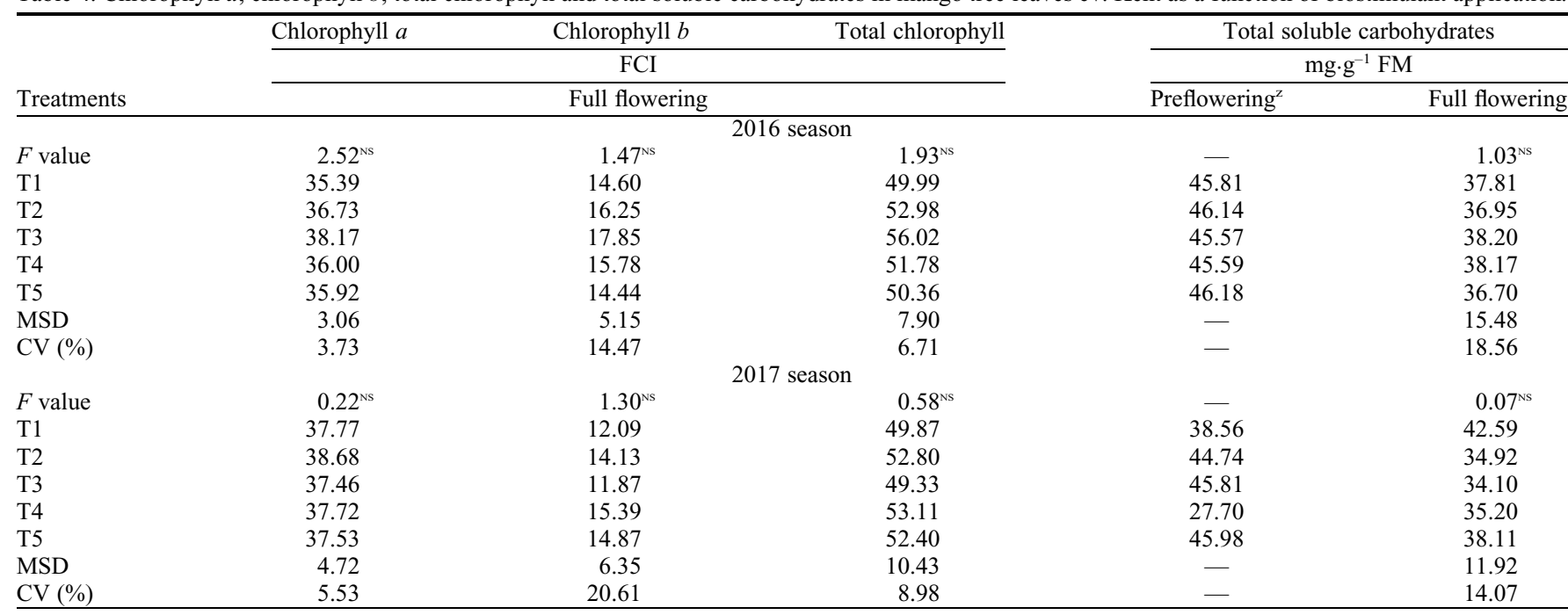

${ }^{\mathrm{z}}$ Data without replications, analysis performed on a composite sample for characterization purposes before the application of the treatments.

$\mathrm{CV} \%=$ coefficient of variation; $\mathrm{FCI}=$ Falker Chlorophyll Index; FM = fresh weight; $\mathrm{MSD}=$ minimum significant difference; $\mathrm{NS}=$ not significant by the Tukey test at $5 \%$ probability; $\mathrm{T} 1=$ control; $\mathrm{T} 2=$ soluble nutrients and $\mathrm{L}-\alpha$-amino acids; $\mathrm{T} 3=$ soluble nutrients and Lithothamnium algae extract; $\mathrm{T} 4=$ soluble nutrients and sucrose; and T5 = soluble nutrients, free amino acids, and Lithothamnium algae extract. 
Table 5. Macro- and micronutrients foliar contents at the full-flowering phase in mango tree cv. Kent as a function of biostimulants application.

\begin{tabular}{|c|c|c|c|c|c|c|c|c|c|}
\hline \multirow[b]{2}{*}{ Treatment } & $\mathrm{N}$ & $\mathrm{P}$ & $\mathrm{K}$ & $\mathrm{Ca}$ & $\mathrm{Mg}$ & $\mathrm{Mn}$ & $\mathrm{Fe}$ & $\mathrm{Zn}$ & B \\
\hline & \multicolumn{5}{|c|}{$\mathrm{g} \cdot \mathrm{kg}^{-1}$} & \multicolumn{4}{|c|}{$\mathrm{mg} \cdot \mathrm{kg}^{-1}$} \\
\hline \multicolumn{10}{|c|}{2016 season } \\
\hline$F$ value & $10.38 * *$ & $0.68^{\mathrm{NS}}$ & $6.8 * *$ & $1.02^{\mathrm{NS}}$ & $2.15^{\mathrm{Ns}}$ & $4.8^{*}$ & $3.94 *$ & $2.82^{\mathrm{NS}}$ & $1.75^{\mathrm{Ns}}$ \\
\hline $\mathrm{T} 1$ & $7.95 \mathrm{~b}$ & 1.50 & $3.43 \mathrm{~b}$ & 15.46 & 0.74 & $99.72 \mathrm{~b}$ & $21.10 \mathrm{~b}$ & 12.70 & 29.87 \\
\hline $\mathrm{T} 2$ & $7.91 \mathrm{~b}$ & 1.44 & $5.88 \mathrm{ab}$ & 14.05 & 0.89 & $141.06 \mathrm{ab}$ & $46.07 \mathrm{a}$ & 11.33 & 30.10 \\
\hline T3 & $13.51 \mathrm{ab}$ & 1.69 & $4.39 \mathrm{~b}$ & 17.85 & 0.80 & $110.56 \mathrm{~b}$ & $23.20 \mathrm{ab}$ & 8.20 & 34.39 \\
\hline $\mathrm{T} 4$ & $15.61 \mathrm{a}$ & 1.52 & $7.25 \mathrm{ab}$ & 14.94 & 0.90 & $106.58 \mathrm{~b}$ & $19.95 \mathrm{~b}$ & 9.39 & 37.32 \\
\hline T5 & $19.93 \mathrm{a}$ & 1.49 & $9.50 \mathrm{a}$ & 17.32 & 0.97 & $187.06 \mathrm{a}$ & $24.90 \mathrm{ab}$ & 12.97 & 27.62 \\
\hline MSD & 6.83 & 0.53 & 4.14 & 7.17 & 0.27 & 74.34 & 24.53 & 5.58 & 13.34 \\
\hline CV (\%) & 23.34 & 15.49 & 30.22 & 19.97 & 14.21 & 25.56 & 40.21 & 22.66 & 18.56 \\
\hline \multicolumn{10}{|c|}{2017 season } \\
\hline$F$ value & $0.73^{\mathrm{NS}}$ & $1.85^{\mathrm{Ns}}$ & $7.21 * *$ & $2.04^{\mathrm{NS}}$ & $0.57^{\mathrm{Ns}}$ & $1.03^{\mathrm{NS}}$ & $9.02 *$ & $3.55^{*}$ & $0,21^{\mathrm{Ns}}$ \\
\hline $\mathrm{T} 1$ & 14.84 & 2.12 & $4.80 \mathrm{ab}$ & 12.90 & 1.01 & 117.98 & $25.40 \mathrm{~b}$ & $12.88 \mathrm{ab}$ & 181.12 \\
\hline $\mathrm{T} 2$ & 15.61 & 1.72 & $2.69 \mathrm{~b}$ & 13.84 & 1.09 & 139.18 & $52.43 \mathrm{a}$ & $9.09 \mathrm{~b}$ & 164.85 \\
\hline T3 & 15.68 & 2.00 & $3.11 \mathrm{~b}$ & 17.97 & 1.10 & 131.62 & $30.83 \mathrm{~b}$ & $9.77 \mathrm{ab}$ & 154.87 \\
\hline $\mathrm{T} 4$ & 15.51 & 1.91 & $4.93 \mathrm{ab}$ & 16.31 & 1.37 & 109.02 & $32.92 \mathrm{~b}$ & $11.36 \mathrm{ab}$ & 162.48 \\
\hline T5 & 15.33 & 1.55 & $7.38 \mathrm{a}$ & 15.66 & 1.30 & 153.33 & $31.52 \mathrm{~b}$ & $17.07 \mathrm{a}$ & 160.65 \\
\hline MSD & 1.78 & 0.75 & 3.11 & 6.34 & 0.91 & 77.61 & 15.56 & 7.59 & 96.11 \\
\hline CV (\%) & 5.12 & 17.98 & 30.11 & 18.34 & 34.42 & 26.43 & 19.93 & 28.01 & 25.86 \\
\hline
\end{tabular}

Means followed by the same letter do not differ significantly by the Tukey test at $5 \%$ probability.

ss $*$, **Nonsignificant or significant at the $P<0.05$ or 0.01 level, respectively.

MSD = minimum significant difference; $\mathrm{T} 1=$ control; $\mathrm{T} 2=$ soluble nutrients and L- $\alpha$-amino acids; T3= soluble nutrients and Lithothamnium algae extract; T4 = soluble nutrients and sucrose; and T5 = soluble nutrients, free amino acids, and Lithothamnium algae extract.

(except for T5), K, Mg, Mn, Fe (except for T2), and $\mathrm{Zn}$ contents. In 2017 from the preflowering to the full-flowering stage, there were reductions in $\mathrm{K}, \mathrm{Ca}, \mathrm{Mg}, \mathrm{Mn}, \mathrm{Fe}$ (except T2), and $\mathrm{Zn}$ contents (except T5) (Tables 2 and 5).

In 2016, the biostimulant-containing soluble nutrients and sucrose (T4) and the biostimulantcontaining soluble nutrients, free amino acids, and extract of Lithothamnium algae (T5) promoted an increase in nitrogen content, with 7.66 and $11.98 \mathrm{~g} \cdot \mathrm{kg}^{-1}$ more nitrogen, respectively, compared with the control treatment (T1).

For potassium content (Table 5) in the two assessed seasons, the highest values were obtained with T5; when T5 averages were compared with the lowest values observed in each season, there was a $276 \%$ increase compared with T1 in 2016 and a 274\% increase compared with T2 (biostimulantcontaining nutrients and $\mathrm{L}-\alpha$-amino acids) in 2017.

The treatments affected the manganese content in 2016, when T5 promoted an $87 \%$ increase $\left(87.34 \mathrm{mg} \cdot \mathrm{kg}^{-1}\right)$ compared with control treatment. The highest iron concentrations in both seasons were obtained with the application of T2, which promoted a $118 \%$ increase in $\mathrm{Fe}$ in 2016 and $106 \%$ in 2017, compared with control treatment. Zinc content in 2017 increased by $32 \%$ with $\mathrm{T} 5$ compared with control treatment; in the same comparison, other treatments using biostimulants presented inferior results compared with the control treatment.

During the full-flowering stage, the total soluble carbohydrate contents (Table 4) were unaffected by the treatments $(P>0.05)$ in either evaluated seasons. In 2016, the average of total soluble carbohydrate content was $37.57 \mathrm{mg} \cdot \mathrm{g}^{-1} \mathrm{FM}$, and in 2017 , it was 36.98 $\mathrm{mg} \cdot \mathrm{g}^{-1} \mathrm{FM}$; in 2016, a mean reduction of 8.2 $\mathrm{mg} \cdot \mathrm{g}^{-1} \mathrm{FM}$ was observed in total soluble carbohydrate levels between the preflowering and full-flowering phases. In 2017, T2, T3, and $\mathrm{T} 5$ promoted a reduction of total soluble carbohydrate levels during the full-flowering stage, and T1 and T4 caused a 4.03 and 7.5 $\mathrm{mg} \cdot \mathrm{g}^{-1} \mathrm{FM}$ increase, respectively.

The panicle length variable was not influenced by the different treatments in 2016 ( $P$ > $0.05)$, but in 2017 , there was a positive effect of the biostimulants on this variable (Fig. 2A). Mango trees treated with T2 produced the longest panicles, with a 7.24-cm $(27.1 \%)$ higher value than that of $\mathrm{T} 1$. The number of fruits per panicle was significant $(P \leq 0.05)$ in both seasons.

Regarding the number of fruits per panicle, in 2016, all biostimulants promoted a greater response, but only T4 was different from the control treatment, with an increase of 0.32 fruit per panicle. In the second season, T3 and T4 promoted greater fruit fixation, with an increase of 0.60 and 0.46 fruits per panicle, respectively, compared with control treatment.

In 2016, T1, T2, and T5 presented similar results regarding the number of fruit per tree (Fig. 2C). The highest number of fruits was seen in T5, with an increase of 54.37 fruits per tree (Fig. 2C) compared with T4, which presented the lowest mean. In 2017, the control treatment produced the lowest number of fruits, and T2 and T5 provided the best results, with a 75.01 increase in fruits per tree for T2 compared with T1.

Production per tree was significantly influenced by the treatments in the two seasons evaluated $(P \leq 0.05)$. In the first season, T5 provided the best result among all biostimulant treatments, but it was statistically similar to the control treatment. In the second season, the control treatment had the lowest production among all treatments; T2 had an increase of $37.4 \mathrm{~kg}$ per tree, and $\mathrm{T} 5$ increased production by $23.1 \mathrm{~kg}$ per tree compared with control.

Pearson's correlation analysis revealed a significant correlation $(P \leq 0.01)$ between total soluble carbohydrates and foliar boron $(r=0.58)$, total soluble carbohydrates, and panicle length $(r=-0.59)$ and a significant correlation $(P \leq 0.05)$ between foliar calcium and number of fruits per panicle $(r=$ $0.54)$.

\section{Discussion}

Faria et al. (2016) reported similar responses to those found in this work for chlorophyll $a, b$, and total contents. In their work, the authors studied different irrigation management of 'Tommy Atkins' mango trees cultivated in a semiarid region and reported maximum values of chlorophyll $a$, $b$, and total as $36.23,15.12$, and 51.35, respectively. In contrast to the study by Schlemmer et al. (2013), in the present study, chlorophyll indices (Table 4) were not associated with nitrogen content (Table 5) due to high $\mathrm{N}$ concentrations, a condition in which chlorophyll meter readings are not influenced by $\mathrm{N}$ content (Blackmer and Schepers, 1994).

Similar to the present study, Prasad et al. (2014) reported high carbohydrate values in the preflowering phase, followed by reduction in the following phases. Maximum levels were obtained in the swelling phase of 'Royal Special' and 'Totapuri' mango tree shoots, $67.587 \mathrm{mg} \cdot \mathrm{g}^{-1} \mathrm{FM}$ and $67.09 \mathrm{mg} \cdot \mathrm{g}^{-1} \mathrm{FM}$, respectively, with reduction of the contents as the panicles developed. Carbohydrate values in the preflowering stage in the present study (Table 4) were lower than those reported by these authors. According to Prasad et al. (2014), the greater carbohydrate content in the early period of panicle emergence may be due to the higher hydrolytic enzyme activity and also leaf metabolite mobilization for panicle development. The reduction of soluble and nonreducing sugars during the fullflowering period is directly correlated with increased flowering percentage and prolonged duration of flowering (Prasad et al., 2014).

Soluble sugars such as sucrose, glucose, and fructose are important substrates for plant metabolism, assisting plants in 
A

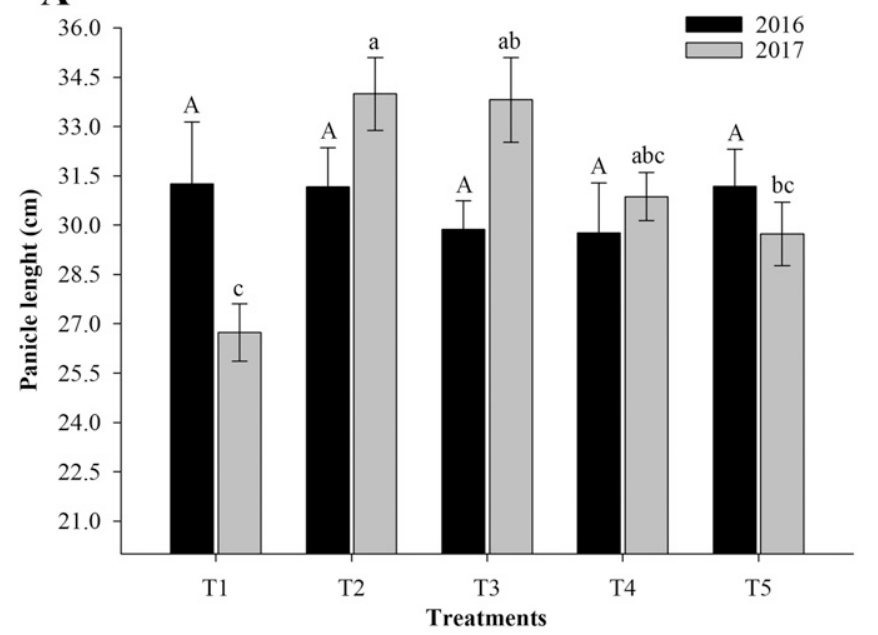

C

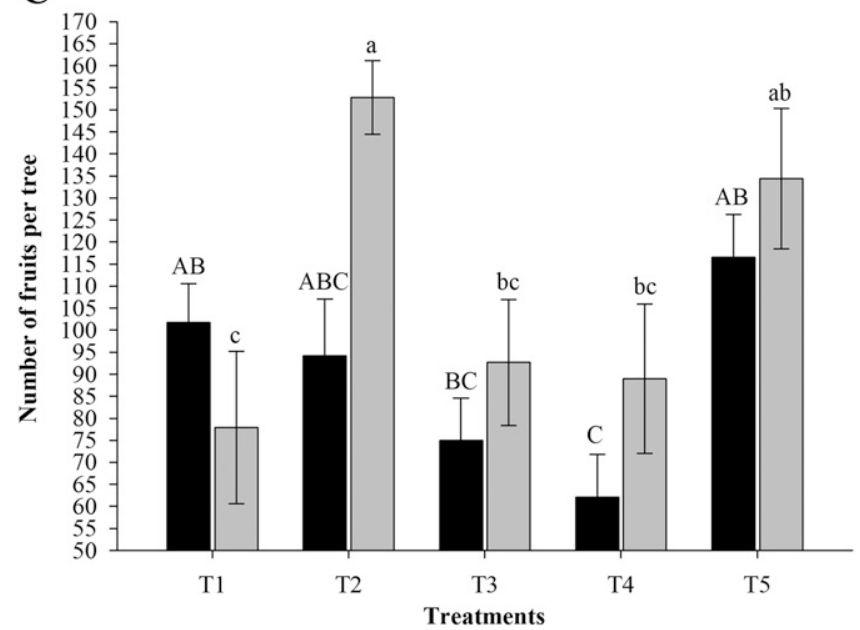

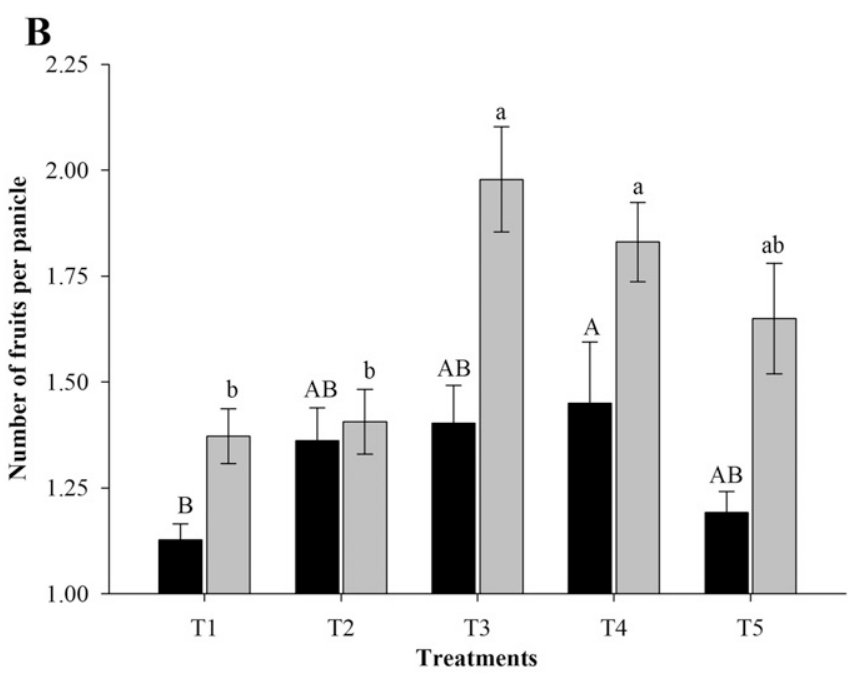

D

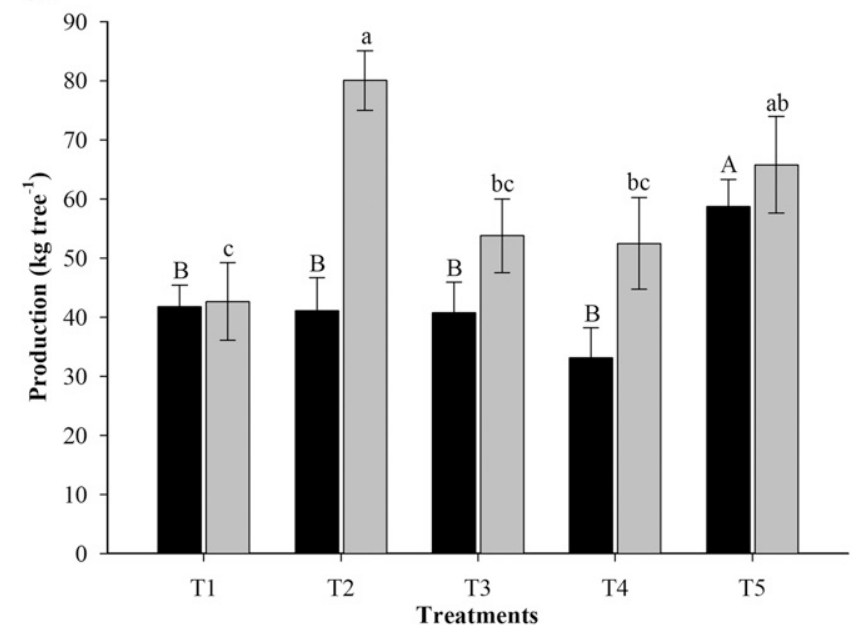

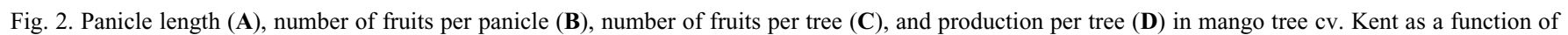
biostimulant application in two seasons (2016 and 2017). Bars with uppercase letters compare data from the 2016 season, and bars with lowercase letters compare data from the 2017 season. Bars with the same letters do not differ by Tukey test at $5 \%$ probability. Error bars indicate standard error of the mean. T1 = control; T2 = soluble nutrients and L- $\alpha$-amino acids; T3 = soluble nutrients and Lithothamnium algae extract; T4 = soluble nutrients and sucrose; and T5 = soluble nutrients, free amino acids, and Lithothamnium algae extract.

physiological events and development and regulating carbon import into the metabolically active drain (Koch, 2004). According to Benkeblia et al. (2005), sugars accumulated during the bud-swelling phase and panicle appearance probably play a key role in reduction of osmotic potential, which promotes the bud's burst process.

The biostimulant that promoted $\mathrm{N}$ content increase (T5) included Lithothamnium algae extract and soluble organic N, which probably increased the nutrient content in plant tissue. In a study with 'Keitt' mango trees, Abd El-Motty et al. (2010) also observed a positive effect of algae extract on leaf nitrogen content. The highest $\mathrm{N}$ content value was $17 \mathrm{~g} \cdot \mathrm{kg}^{-1}, 70 \%$ higher than that found in the control treatment $\left(10 \mathrm{~g} \cdot \mathrm{kg}^{-1}\right)$.

According to Quaggio (1996), adequate nitrogen levels are between 12 and $14 \mathrm{~g} \cdot \mathrm{kg}^{-1}$, so the result obtained in the 2016 season with T5 is considered excessive $\left(>16 \mathrm{~g} \cdot \mathrm{kg}^{-1} \mathrm{~N}\right)$; T4 is classified as high and T1 and T2 as deficient $\left(<8 \mathrm{~g} \cdot \mathrm{kg}^{-1} \mathrm{~N}\right)$. Only $\mathrm{T} 3$ presented $\mathrm{N}$ content values in a suitable range for the species. According to Urban et al. (2006), due to the high nitrogen demand during flowering, it is common for $\mathrm{N}$ content to decrease between the preflowering and full-flowering phases. However, in 2016, T5 promoted N increase, and in 2017, all treatments caused $\mathrm{N}$ increase, with a high nitrogen content range (14.84-15.68 $\left.\mathrm{g} \cdot \mathrm{kg}^{-1}\right)$.

There are controversies in the literature regarding the ideal leaf $\mathrm{N}$ content during flowering for mango tree cultivation. According to Pimplaskar and Bhargava (2003), the ideal content ranges between 8.9 and 19.3 $\mathrm{g} \cdot \mathrm{kg}^{-1}$, but Davenport (2003) reported that it should be between 11 and $14 \mathrm{~g} \cdot \mathrm{kg}^{-1}$ to avoid vegetative rather than reproductive new shoots. According to these authors, the leaf $\mathrm{N}$ content should not exceed $14 \mathrm{~g} \cdot \mathrm{kg}^{-1}$ at this stage and, considering this criterion, $\mathrm{T} 4$ and T5 in 2016 and all treatments in 2017 would not be adequate. However, the productive variables obtained for these treatments indicate the contrary.
According to Quaggio (1996), the ideal potassium content ranges from 5 to $10 \mathrm{~g} \cdot \mathrm{kg}^{-1}$. In 2016, T1 and T3 presented low levels of this nutrient; in both assessed seasons, T5 promoted adequate potassium levels. Potassium is related to photosynthesis, carbohydrate transport, and plant water and osmotic regulation, protective antistress factors (Marschner, 2012) that directly influence fruit retention. When evaluating the effect of potassium sprays on fruit retention, fruit quality, and fruit yield of 'Hindi' mango trees, Baiea et al. (2015) found a positive relationship between leaf potassium levels and fruit retention. Cavalcante et al. (2016) applied $\mathrm{KCl}$ doses in 'Palmer' mango trees cultivated in Casa Nova, Brazil, and obtained a maximum leaf potassium content $\approx 9.2$ $\mathrm{g} \cdot \mathrm{kg}^{-1}$, similar to the maximum values obtained in the present study with T5.

In 2016, the best result observed for iron content was still considered inferior to the minimum recommended ( 50 to $200 \mathrm{mg} \cdot \mathrm{kg}^{-1}$ ). In 2017, T2 provided an adequate iron level 
and was the treatment that provided the highest levels of nutrients; it should be noted that among the treatments, T2 was the only one to provide elevation in iron concentration during the full-flowering phase.

The zinc levels observed for all treatments in both seasons evaluated are below the ideal recommended ( 20 to $40 \mathrm{mg} \cdot \mathrm{kg}^{-1}$ ); according to Politi et al. (2013), Fe and $\mathrm{Zn}$ deficiencies in the northeastern semiarid region mango tree orchards are common, whereas the macronutrients are usually satisfactorily supplied. T2 and T5, with better nutritional performance for iron and zinc, respectively, have amino acids in common in their composition. Amino acids play a role in protein synthesis as intermediate compounds of endogenous plant hormones and have a complexing effect on nutrients (Taiz et al., 2017). Including amino acids and nutrients in biostimulant formulas may provide the best nutritional balance, a fact that was evident through the effect of biostimulants on most of the nutrients that were affected by the treatments.

Regardless of the treatment, all plants had foliar calcium contents below the range recommended by Quaggio (1996), that is, between 20 and $40 \mathrm{~g} \cdot \mathrm{kg}^{-1}$. According to Stino et al. (2011) calcium is necessary for pollen development and germination, pollen tube growth, and sugar synthesis and accumulation; reduced calcium quantities can thus compromise fruit retention, production, and quality.

Table 5 shows that boron is the nutrient that presented greater variation between seasons. The boron contents for all the treatments in 2016 were considered low $(<50$ $\left.\mathrm{mg} \cdot \mathrm{kg}^{-1}\right)$ and in 2017 considered excessive (>150 mg. $\mathrm{kg}^{-1}$ ) (Quaggio, 1996), although the plants did not present symptoms of toxicity; according to Silva et al. (2014) boron deficiency reduces the intensity of flowering and pollination and negatively interferes with the absorption and use of calcium; the fruits tend to be smaller, which is reflected in low production. When evaluating different boron fertilization strategies in 'Palmer' mango trees to reduce the occurrence of physiological disorders, Barbosa et al. (2016) obtained a 133\% higher fruit yield in their most successful treatment compared with control.

The significant boron increases from 2016 to 2017 , regardless of the treatment, is justified by the specific management of the nutrient adopted during the second cycle. The recommendations of Barbosa et al. (2016) were followed: two fertigations with $50 \mathrm{~g} /$ plant of $\mathrm{H}_{3} \mathrm{BO}_{3}$ plus five sprays with $\mathrm{H}_{3}$ $\mathrm{BO}_{3}$, the first two $(0.3 \%)$ and remaining $(0.2 \%)$.

Soluble carbohydrates are one of the main factors related to plant photosynthetic efficiency and, consequently, growth, development, and adaptability to different environments and adverse conditions (Sami e Hayat, 2018). The significant and negative correlation between soluble leaf carbohydrate and panicle length is because both variables were measured in the fullflowering stage. It is noteworthy that the accumulated soluble carbohydrates in the leaves constitute an important energy source for flower and fruit formation and development; therefore, the development of longer panicles demands larger amounts of carbohydrates. According to Prasad et al. (2014), in the flowering phase, carbohydrate demand exceeds its daily production, and therefore the more intense flowering, characterized by larger panicles and a greater number of flowers, occurs concomitantly with the reduction of the soluble carbohydrates.

The significant and positive correlation between the foliar boron levels and soluble carbohydrates can be explained by the fact that boron plays a fundamental role in carbohydrate biosynthesis and translocation (Taiz et al., 2017). When evaluating boric acid doses applied via leaves in 'Zebda' mango trees, Ali et al. (2017) verified a significant and positive correlation between the reduced sugar content and leaf boron levels.

The calcium increase correlated with the increase in the number of fruits per panicle is associated with the nutrient's function in maintaining cell wall and middle lamella integrity, thus reducing fruit drop. Similar results have been observed by other authors. Hafle et al. (2003) described improvement in 'Tommy Atkins' mango fruit retention when spraying with $2 \%$ calcium nitrate. When evaluating the performance of calciumcontaining biostimulants, Khattab et al. (2016) found that the higher retention of fruits was associated with higher doses of biostimulants.

Regarding biostimulant effect on panicle length, Mouco et al. (2011) evaluated the action of different plant regulators on the vegetative and floral shoots of 'Kent' mango trees cultivated in Petrolina, Brazil, and verified differences for this variable, with results varying from 13.25 to $41.24 \mathrm{~cm}$, a broader range than that found in the present study. According to Husen et al. (2012), high PBZ doses applied in mango trees tend to compact the panicles. This effect can be observed in Fig. 2A where the control treatment presents reduced panicle length in the second season compared with the first, indicating a possible residual effect of PBZ, whereas biostimulant treatments led to panicle expansion, minimizing this PBZ effect.

The positive effect of the biostimulants containing algae extract on the retention of mango fruits may be related to its nutrients, but especially to the presence of cobalt (Aslam et al., 2010). Cobalt reduces tissue senescence in the abscission process by inhibiting ACC oxidase activity and reducing the ethylene production ( $\mathrm{Li}$ et al., 2005). When evaluating combinations of seaweed extract with yeast extract in 'Keitt' mango fruit retention and production, Abd El-Motty et al. (2010) verified increases for both variables until the maximum dose was applied, and the number of fruits per panicle went from 1.35 to 3.72 in the first assessed year and from 3.02 to 4.4 in the second year.
When comparing Fig. 2B and C, it can be observed that the treatments with the highest average number of fruits per panicle did not necessarily have a higher number of fruits per tree. Similar results were reported by Majumder et al. (2011) when evaluating different mango tree genotypes grown in Bangladesh. These authors noted that there is no direct relation between the two variables, in part due to the variation in the number of panicles per branch, demonstrating that trees with a higher number of fruit per panicle may not have higher yield because they have a smaller number of panicles.

Comparing Fig. 2B and D, for 2017, although $\mathrm{T} 2$ has a lower number of fruits per panicle (Fig. 2B) compared with T3 and T4 (1.98 and 1.83 fruit per panicle), its tree production was higher than the respective treatments at $48.8 \%$ and $52.5 \%$ (Fig. 2D). When applying biostimulants during the floral induction phase of 'Tommy Atkins' mango trees cultivated in semiarid conditions, Gomes et al. (2008) demonstrated a $10.2 \%$ increase in production per tree. These authors confirmed that the number of panicles at the end of the flowering period for trees treated with biostimulants was greater than that the control treatment with 14.24 panicles per tree.

The differences observed between the 2016 and 2017 in the number of fruits per panicle (Fig. 2B) and in production (Fig. 2D) may be associated with the use of PBZ in floral management. PBZ is used to inhibit the gibberellin synthesis, but studies have shown that the plant regulator also inhibits the synthesis of ethylene (Ahmad et al., 2015; Antunes et al., 2008). According to Sexton and Roberts (1982), ethylene is directly involved in factors that promote mango fruit abscission; thus, by inhibiting synthesis of ethylene, PBZ also minimizes fruit drop, providing an increased number of fruit per tree.

In both assessed seasons, the PBZ dose used was $9 \mathrm{~mL}$ per meter of crown diameter, which was higher than that recommended by the manufacturer $\left(\leq 6 \mathrm{~mL} \cdot \mathrm{m}^{-1}\right)$ due to the intense vegetative vigor of 'Kent' mango trees (Albuquerque et al., 2002). According to Sharma and Awasthi (2005), at the end of each harvest, residues of PBZ remain in the soil, and these residues accumulate with continuous use in consecutive crops (Reddy e Kurian, 2008). Therefore, the high dose associated to the previous harvest residues may have favored the higher number of fruits per panicle in the second year evaluated.

Differences in production data between the 2016 and 2017 seasons may have been influenced by divergences in climatic variables between these years (Fig. 1). From the beginning of the flowering to the full bloom of the 2016 season (July/August), high maximum temperatures were recorded, mostly higher than $30{ }^{\circ} \mathrm{C}$, with a maximum of $37.4{ }^{\circ} \mathrm{C}$ (August). During the same phase in 2017 (July), temperatures were mostly below $30^{\circ} \mathrm{C}$, with an average of $23^{\circ} \mathrm{C}$. According to Lima Filho et al. (2002), the occurrence of 
maximum temperatures higher than $30{ }^{\circ} \mathrm{C}$ and minimum higher than $25{ }^{\circ} \mathrm{C}$ favors vegetative growth, whereas temperatures ranging between $18{ }^{\circ} \mathrm{C}$ (minimum) and $28{ }^{\circ} \mathrm{C}$ (maximum) favor flowering. The latter condition is similar to what occurred during the 2017 season (Fig. 1B) and may have favored increased production. Dag et al. (2000) found that for the Kent cultivar, temperatures close to $30{ }^{\circ} \mathrm{C}$ are most favorable to pollen germination and pollen penetration in the ovule, and temperatures $\approx 37.5{ }^{\circ} \mathrm{C}$ have a harmful effect on these variables, reflecting in reduced production.

When observing the striking differences in the climatic variables between the two seasons evaluated in this study, especially in temperature, as well as in the responses to the biostimulants in these harvests, it appears that the biostimulant effect is influenced by the prevailing climate during the application period.

\section{Literature Cited}

Abd-El-Motty, E.Z., M.F.M. Shahin, M.H. Elshiekh, and M.M.M. Abd-El-Migeed. 2010. Effect of algae extracts and yeast application on growth, nutritional status, yield and fruit quality of 'Keitt' mango trees. Agr. Biol. J. N. Amer. 1(3):421-429.

Ahmad, I., J.M. Dole, and B.E. Whipker. 2015. Paclobutrazol or uniconazole effects on ethylene sensitivity of potted ornamental plants and plugs. Scientia Hort. 192:350-356.

Ahmed, F.F., A.M.K. Abdelaal, and M.M. Refaai. 2015. Impact of seaweed extract as a partial replacement of mineral $\mathrm{N}$ fertilizers on fruiting of Taimour mango trees. Egypt. J. Hort. 42(1):655-664.

Albuquerque, J.A.S., V.D. Medina, and M.A.C. Mouco. 2002. Indução floral, p. 259-276. In: P.J.C. Genú and C.A.Q. Pinto (eds.). A cultura da mangueira. Vol. 13. Embrapa Informação Tecnológica, Brasília.

Ali, M.S., M.A. Elhamahmy, and A.F. El-Shiekh. 2017. Mango trees productivity and quality as affected by boron and putrescine. Scientia Hort. 216:248-255.

Antunes, A.M., E.O. Ono, A.C. Sampaio, and J.D. Rodrigues. 2008. Physico-chemical and harvest time alterations in pineapple fruits 'Smooth Cayenne' caused by paclobutrazol. Braz. Arch. Biol. Technol. 51(1):19-26.

Aslam, M.N., J.M. Kreider, T. Paruchuri, N. Bhagavathula, M. Silva, R.F. Zernicke, S.A. Goldstein, and J. Varani. 2010. A mineral-rich extract from the red marine algae Lithothamniun calcareum preserves bone structure and function in female mice on a Western-style diet. Calcif. Tissue Intl. 86(4):313-324.

Baiea, M.H.M., H.E.M. El-Badawy, and S.F. ElGioushy. 2015. Effect of potassium, zinc and boron on growth, yield and fruit quality of Keitt mango trees. Res. J. Pharm. Biol. Chem. Sci. 6(4):800-812.

Barbosa, L.F.S., I.H.L. Cavalcante, and A.M.N. Lima. 2016. Desordem fisiológica e produtividade de mangueira cv. Palmer associada à nutrição de boro. Rev. Bras. Frutic. 38(1):1-10.

Benkeblia, N., S. Onodera, and N. Shiomi. 2005. Variation in 1-fructo-exohydrolase (1-FEH) and 1-kestose-hydrolysing (1-KH) activities and fructo-oligosaccharide (FOS) status in onion bulbs. Influence of temperature and storage time. J. Sci. Food Agr. 85:227-234.
Blackmer, T.M. and J.S. Schepers. 1994. Techniques for monitoring crop nitrogen status in corn. Commun. Soil Sci. Plant Anal. 25:17911800.

Castro, P.R.C. 2006. Agroquímicos de controle hormonal na agricultura tropical. Piracicaba, ESALQ. Divisão de Biblioteca e Documentação. (Série Produtor Rural, 32).

Cavalcante, I.H.L., A.M.N. Lima, M.A. Carneiro, M.S. Rodriguez, and R.L. Silva. 2016. Potassium doses on fruit production and nutrition of mango (Mangifera indica L.) cv. Palmer. Rev. Fac. Agron. 33(4):418-432. (LUZ).

Dag, A., D. Eisenstein, and S. Gazit. 2000. Effect of temperature regime on pollen and the effective pollination of 'Kent' mango in Israel. Scientia Hort. 86(1):1-11.

Davenport, T.L. 2003. Management of flowering in three tropical and subtropical fruit tree species. HortScience 38:1331-1335.

$\mathrm{Du}$ Jardin, P. 2012. The science of plant biostimulants - a bibliographic analysis, ad hoc study report. European Commission, Brussels, Belgium.

Dubois, M., K.A. Gilles, J.K. Hamilton, P.A Rebers, and F. Smith. 1956. Colorimetric method for determination of sugars and related substances. Anal. Chem. 28(3):350-356.

El-Hendawy, S.E., Y. Hu, and U. Schimidhalter. 2005. Growth, ion content, gas exchange, and water relations of wheat genotypes differing in salt tolerances. Austral. J. Agr. Res. 56(2):123134.

Food and Agriculture Organization of the United Nations. 2017. FAOSTAT database Crops. FAO-ESS, Rome, Italy. 20 Dec. 2017. <http:// faostat.fao.org/site/339/default.aspx>.

Faria, L.N., S.L.R. Donato, M.R. Dos Santos, and L.G. Castro. 2016. Nutrient contents in 'Tommy Atkins' mango leaves at flowering and fruiting stages. J. Brazil Assoc. Agr. Eng. 36(6):1073-1085.

Filgueiras, H.A.C., T.B.F. Amorim, J.B. Menezes, and R.E. Alves. 2000. Colheita e manuseio póscolheita, p. 22-37. In: H.A.C. Filgueiras and A. Cunha (eds.). Frutas do Brasil: Manga póscolheita. Embrapa Agroindústria Tropical, Fortaleza, Brazil.

Genú, P.J.C. and A.C.Q. Pinto (eds.). 2002. The culture of mango. Embrapa Informação Tecnológica, Brasília, BR.

Gomes, E.C.S., J. Barbosa, W.S. Ribeiro, M.A.D. Marques, J.O. Perez, J.L.O. Freire, and A.N Lima. 2008. Utilização do bioestimulante Ecolife na indução de florada em manga (Mangifera indica L.) "Tommy Atkins" no vale do São Francisco, em Petrolina-PE. Eng. Amb. Pesq. Tec. 5(2):86-93.

Hafle, O.M., F.I. Delfino, V. Mendonça, and S.E. Araujo Neto. 2003. Flowering and production of mango cv. Tommy Atkins using ethrel, potassium nitrate and calcium nitrate. Rev. Ciênc. Agr. 3:145-152.

Husen, S., S.A. Kuswanto, and N. Basuki. 2012. Induction of flowering and yield of mango hybrids using paclobutrazol. J. Agr. Food Tech. 2(9): 153-158

Instituto Brasileiro de Geografia e Estatística. 2018. Produção Agrícola Municipal, 2016. Rio de Janeiro, Brazil. 2 Feb. 2018. <http:// www.ibge.gov.br/estadosat/>.

Kamel, H.M. 2014. Impact of garlic oil, seaweed extract and imazalil on keeping quality of Valencia orange fruits during cold storage. J. Hort. Sci. Ornam. Plants 6(3):116-125.

Khattab, M.M., A.E.A. Shaban, and A.E. Hassan. 2016. Impact of foliar application of calcium, boron and amino acids on fruit set and yield of
Ewais and Fagry Kelan mango cultivars. J. Hort. Sci. Ornam. Plants 8(2):119-124.

Koch, K. 2004. Sucrose metabolism: Regulatory mechanisms and pivotal roles in sugar sensing and plant development. Curr. Opin. Plant Biol. 7(3):235-246

Li, C.Z., D. Wang, and G.X. Wang. 2005. The protective effects of cobalt on potato seedling leaves during osmotic stress. Bot. Bull. Acad. Sin. 46:119-125.

Lima Filho, J.M., J.S. Assis, A.H.C. Teixeira, G.A.P. Cunha, and M.T. Castro Neto. 2002. Ecofisiologia, p. 243-257. In: P.J.C. Genú and A.C.Q. Pinto (eds.). A cultura da mangueira. Embrapa Informação Tecnológica, Brasília, Brazil.

Machado, L.P., S.T. Matsumoto, C.M. Jamal, M.B. Silva, D.C. Centeno, P. Colepicolo Neto, L.R. Carvalho, and N.S. Yokoya. 2014. Chemical analysis and toxicity of seaweed extracts with inhibitory activity against tropical fruit anthracnose fungi. J. Sci. Food Agr. 94(9):17391744.

Majumder, D.A.N., L. Hassan, M.A. Rahim, and M.A. Kabir. 2011. Studies on physiomorphology, floral biology and fruit characteristics of mango. J. Bangladesh Agr. Univ. 9(2):187-199.

Marschner, P. 2012. Mineral nutrition of higher plants. 3rd ed. Academic Press, London.

Mouco, M.A.C., E.O. Ono, and J.D. Rodrigues. 2011. Controle do crescimento vegetativo e floração de mangueiras cv. Kent com reguladores de crescimento vegetal. Rev. Bras. Frutic. 33(4):1043-1047.

Pimplaskar, M. and B.S. Bhargava. 2003. Leaf and soil nutrient norms in mango (Mangifera indica L.) grown in tribal belt of southern Gujarat. J. Indian Soc. Soil Sci. 51:268-272.

Politi, L.S., R.A. Flores, J.A.S. Silva, P.G.S. Wadt, P.A.C. Pinto, and R.M. Prado. 2013. Estado nutricional de mangueiras determinado pelos métodos DRIS e CND. Rev. Bras. Eng. Agr. Ambient. 17(1):11-18.

Prasad, S.R.S., Y.T.N. Reddy, K.K. Upreti, and A.N. Rajeshwara. 2014. Studies on changes in carbohydrate metabolism in regular bearing and "off" season bearing cultivars of mango (Mangifera indica L.) during flowering. Intl. J. Fruit Sci. 14(4):437-459.

Quaggio, J.A. 1996. Adubação e calagem para a mangueira e qualidade dos frutos, p. 106-135. In: A.R. São José, I.V.B. Souza, J. Martins Filho, and O.M. Morais (eds.). Manga: Tecnologia de produção e mercado. DBZ/UESB, Vitória da Conquista, Brazil.

Ramírez, F. and T.L. Davenport. 2010. Mango (Mangifera indica L.) flowering physiology. Scientia Hort. 126(2):65-72.

Reddy, Y.T.N. and R.M. Kurian. 2008. Cumulative and residual effects of paclobutrazol on growth, yield and fruit quality of 'Alphonso' mango. J. Hort. Sci. 3(2):119-122.

Ribeiro, R.F., J.T. Lobo, I.H.L. Cavalcante, I.G.P Tenreiro, and D.D. Lima. 2017. Bioestimulante na produção de mudas de videira cv. Crimson seedless. Sci. Agrar. 8(4):36-42.

Sami, F. and S. Hayat. 2018. Effect of glucose on the morpho-physiology, photosynthetic efficiency, antioxidant system, and carbohydrate metabolism in Brassica juncea. Protoplasma 255(4):1-14.

Schlemmer, M., A. Gitelson, J. Schepers, R. Ferguson, Y. Peng, J. Shanahan, and D. Rundquist. 2013. Remote estimation of nitrogen and chlorophyll contents in maize at leaf and canopy levels. Intl. J. Appl. Earth Obs. Geoinf. 25: $47-54$. 
Sexton, R. and J.A. Roberts. 1982. Cell biology of abscission. Annu. Rev. Plant Physiol. 33:133-162.

Sharma, D. and M.D. Awasthi. 2005. Uptake of soil paclobutrazol in mango (Mangifera indica L.) and its persistence in fruit and soil. Chemosphere 60(2):164-169.

Siddiq, M., J.K. Brecht, and J.S. Sidhu (eds.). 2017. Handbook of mango fruit: Production, postharvest science, processing technology and nutrition. Wiley-Blackwell, Oxford, England.

Silva, A.C., A.P. Souza, S. Leonel, M.E. Souza, D.P. Ramos, and A.A. Tanaka. 2014. Growth and flowering of five mango cultivars under subtropics conditions of Brazil. Amer. J. Plant Sci. 5(3):393-402.
Silva, F.A.S. and C.A.V. Azevedo. 2016. The Assistat Software Version 7.7 and its use in the analysis of experimental data. Afr. J. Agr. Res. 11:3733-3740.

Singh, Z., A.U. Malik, and T.L. Davenport. 2005. Fruit drop in mango, p. 111-154. In: J. Janick (ed.). Horticultural reviews, v. 31. Wiley, Hoboken, NJ.

Singh, Z. and J. Janes. 2000. Regulation of fruit set and retention in mango with exogenous application of polyamines and their biosynthesis inhibitors. Acta Hort. 509:675-680.

Stino, R.G., S.M. Abd El-Wahab, S.A. Habashy, and R.A. Kelani. 2011. Productivity and fruit quality of three mango cultivars in relation to foliar sprays of calcium, zinc, boron or potassium. J. Hort. Sci. Ornam. Plants 3(2): 91-98.

Taiz, L., E. Zeiger, I.M. Moller, and A. Murphy. 2017. Fisiologia e desenvolvimento vegetal. 6th ed. Artmed, Porto Alegre, Brazil.

Tedesco, M.J., C. Gianello, C.A. Bissani, H. Bohnen, and S.J. Volkweiss. 1995. Análises de solo, plantas e outros materiais. 2nd ed. Universidade Federal do Rio Grande do Sul, Faculdade Agronomia, Porto Alegre, Brazil.

Urban, L., P. Montpied, and F. Normand. 2006. Season effects on leaf nitrogen partitioning and photosynthetic water use efficiency in mango. J. Plant Physiol. 163(1):48-57. 